\title{
Analysis of the Views of Preschool Teachers on Their Professional Work
}

\author{
Hikmet Zelyurt ${ }^{1, *}$ \\ ${ }^{1}$ Faculty of Education, Inonu University, Malatya, Turkey \\ *Correspondence: Faculty of Education, Inonu University, Malatya, Turkey. Tel: 90-422-377-4192. E-mail: \\ hikmet.zelyurt@inonu.edu.tr
}

Received: July 27, 2018

Accepted: August 18, $2018 \quad$ Online Published: September 17, 2018

doi:10.5430/wje.v8n5p24

URL: https://doi.org/10.5430/wje.v8n5p24

\begin{abstract}
The general objective of the present study was to assess the views of pre-school teachers on their professional work. Since the research aimed to describe the current status of professional work, it was designed with the survey model. The study group included 105 pre-school teachers determined with the single-stage sampling method. The data were collected with Views on Professional Work Questionnaire for teachers (MEB, 2006). The data obtained in the study were analyzed using the SPSS 21.0 software. The Mann-Whitney U-Test and the Independent Samples t-Test were used to compare the differences between the quantitative data when there are two groups, and one-way ANOVA was used to compare the group parameters between more than two groups. The study results demonstrated that the views of pre-school teachers on professional work were at a good level in terms of both the beginning and the end of the year professional work and the fulfillment of teachers' needs by the professional work. However, the views of pre-school teachers on the beginning and the end of the year professional work and the fulfillment of teachers' needs by the professional work did not demonstrate a significant difference based on gender, seniority in the teaching profession, place of employment and participation in activities on vocational studies during the previous three years variables.
\end{abstract}

Keywords: pre-school teachers, professional work, views

\section{Introduction}

Education dates back to the first human. It is known that during antiquity, the individuals who were engaged in hunting and gathering convey their knowledge on hunting and gathering to each other. The transfer of information that started with this process has been advanced with the spread of the invention and has gradually gained an institutional structure. Comprehensive physical and psychological formability of humans necessitate education and learning (Ergün, 1996:134). In general, education is defined as the creation of permanent behavioral changes in individual. It is expected that the changes and developments in the behavior of the individuals would be in the desired direction in the process of education (Demirel, Seferoğlu \& Yağc1, 2001). When studied as a social institution, the main elements of the education system include students, teachers, educational programs, educational experts, administrators, and physical and economic resources. Teachers are the most fundamental element among these educational components. The more qualified the teacher is in her or his field, the quality of education increases accordingly. Thus, it is quite important for the teachers to receive both pre-service and in-service training in the best way possible (Şişman, 1999). Education and teachers shape the raw material called labor force. Here, especially the role of the teacher is significant. Teachers function as the role models for preschool children, the children imitate teachers, and almost entirely embrace their character (Kavcar, 1988, Şişman, 1999, Tandoğan, 2001 \& Ulcay, 1983). Education could affect individuals, families, and the entire community directly or indirectly on social, psychological, cultural, economic, etc. aspects positively or negatively. Thus, it is necessary for administrators, staff and society to understand the significance of education. And it is of utmost importance that quality educational services are provided.

The 0-6 age group children exhibit the fastest physical, mental, social and emotional development. The child begins to adapt to daily life during this period. Furthermore, the child has social and psychological needs that must be met. If the child's needs and adaptation to daily life are left to improvised experiences, problems would be experienced 
and these problems would last a lifetime. A qualified pre-school education helps the child to adapt to daily life. Pre-school education institutions also include physical and social environment in order to provide for the above-mentioned adaptation process (Türkoğlu, 1994). Pre-school education is a planned and formal training process based on the age and skills of children that includes their cognitive, cultural, emotional, social and physical development in accordance with their own traits and abilities (Konakl1, 1992; Yilmaz, 1991). According to Oktay (1993), in the most comprehensive sense, pre-school education could be defined as all educational activities conducted after the birth of the child until primary education. Development of the children's self-esteem, recognition of their places, roles and responsibilities in the society, development of special skills and to create future content individuals are possible with pre-school education (Acun \& Erten, 1993). Carefully selected, well-trained preschool teachers are very important for subsequent education and instruction levels, and professional and social life of the children. Necessary studies on teacher training needs to be conducted to improve the professional qualifications of teachers (Gürdal, Sağırlı \& Oredi, 2000; Oktay, 1993). The teacher is the most important element in the education system. The success of educational activities depends on the qualifications and skills of teachers and other educational staff. No training model could produce more than the quality of the personnel who would operate the model. Therefore, it could be stated that a school could be as good as the teachers that teach at that school (Kavcar, 1988). In-service training is the training provided for the employees to develop their professional knowledge and skills on the job (TDK, 2018). In-service training encompasses all educational activities that aim to improve professional knowledge and skills of the teachers to improve their professional performance and productivity (Şişman, 1999). In-service training has a diverse significance in vocational development of employees. In-service training is essential and important in all vocational fields. However, in-service teacher training has a special significance. In a society, teachers are responsible for the training of productive, creative, productive, professional generations and citizens who are aware of their social responsibilities. Teachers constitute a professional group that implements education policies that the state develops based on research results, affect these policies through their implementation, and bear the responsibility for the production of the ideal type desired by the society (Varış, 1973). Vocational studies are the work conducted by teachers between the end of the instruction on July $1^{\text {st }}$ and September $1^{\text {st }}$ and the work they conduct at school during the academic year as depicted in the syllabus (MEB, 2006: 10). Vocational studies conducted by the teachers at the beginning, the end and during the academic year are called seminar studies in educational society and thus, it was deemed adequate to call these studies as Vocational Seminar Studies. The objectives of vocational studies include the improvement of the quality of education and the efficiency of instruction and learning, to contribute to the professional development of teachers, to inform teachers about the curricula content and avail a discussion environment, to provide an environment where teachers could share their knowledge and experiences and to develop original studies (MEB, 2017). It would be adequate to provide various seminars, panels and conferences on the problems experienced in in-service training programs and to provide necessary incentives and support for the teachers to participate in these activities at various times to advance the teachers employed in preschool education in their field and to raise their awareness on new knowledge, developments and changes. However, attention should be paid to the significance of conducting in-service training activities (Zembat \& Bilgin, 1996). Education is grouped under two categories; formal and informal education. Although the formal education is planned and programmed, informal education occurs indiscriminately. Formal education is also categorized as formal education and non-formal education (Celep, 2010:15-16). One of the important services provided within the scope of non-formal education is in-service training. Individuals who complete the pre-service training need to continue their education in their own fields to develop and improve themselves after they start to provide professional services. Thus, in-service training is essential and crucial for professional development and progress (Demirel \& Kaya, 2014: 11-13).

The ability of the preschool teachers in particular, to follow the rapid innovations, to improve themselves and continue their training is quite significant for the educational and instructional activities of 0-6 years old children. The education provided by pre-school teachers corresponds to a critical period in every sense for child development. Thus, professional development of pre-school teachers is quite important. The general objective of the present study was to analyze the views of pre-school teachers on their professional work. Based on this general objective, the following research questions were identified:

a) What are the views of pre-school teachers on their professional work based on the professional work conducted at the beginning of the academic year, the professional work conducted at the end of the academic year and the fulfillment of teachers' needs by the topics of professional work?

b) Is there a significance difference between the views of preschool teachers on professional work based on gender? 
c) Is there a significance difference between the views of preschool teachers on professional work based on the place of employment?

d) Is there a significance difference between the views of preschool teachers on professional work based on their professional seniority?

e) Is there a significance difference between the views of preschool teachers on professional work based their participation in professional activities during the previous three years?

\section{Method}

\subsection{Research Model}

The research was designed with the survey model since it aimed to describe the current status of the professional work conducted by preschool teachers at the beginning, during and at the end of the academic year. The survey model is a research approach that aims to describe the past or present as is. The phenomenon, individual or object that is the subject of the investigation is defined as is and within its circumstances (Karasar, 2013).

\subsection{The Study Group}

The study group included 105 pre-school teachers employed in Malatya province, Turkey, and selected with a single-stage sampling during the 2017-2018 academic year.

Table 1. The Study Group Demographics

\begin{tabular}{|c|c|c|c|}
\hline \multicolumn{2}{|c|}{ Variable } & \multirow{2}{*}{$\begin{array}{c}\mathbf{n} \\
94\end{array}$} & \multirow{2}{*}{$\begin{array}{c}\mathbf{\%} \\
89.5\end{array}$} \\
\hline Gendar & Female & & \\
\hline Gender & Male & 11 & 10.5 \\
\hline \multirow{2}{*}{ Location } & Province & 74 & 70.5 \\
\hline & District & 31 & 29.5 \\
\hline \multirow{5}{*}{ Seniority } & $1-5$ years & 10 & 9.5 \\
\hline & $6-10$ years & 40 & 38.1 \\
\hline & $11-15$ years & 42 & 40.0 \\
\hline & $16-20$ years & 9 & 8.6 \\
\hline & 21 years and over & 4 & 3.8 \\
\hline \multirow{3}{*}{ Participation in Activities } & $1-2$ times & 29 & 27.6 \\
\hline & $3-4$ times & 43 & 41.0 \\
\hline & 5 times or more & 33 & 31.4 \\
\hline Total & & 105 & 100 \\
\hline
\end{tabular}

As seen in the Table $1.89 .5 \%$ of the study group was female and $10.5 \%$ was male. While $70.5 \%$ of the teachers were employed in the provincial center, $29.5 \%$ were employed in the provincial districts. In the study group, the seniority of $9.5 \%$ of the teachers was $1-5$ years, $38.1 \%$ was $6-10$ years, $40 \%$ was $11-15$ years and $12.4 \%$ was 16 years. Furthermore, $27.6 \%$ of the teachers participated in 1 or 2 vocational activities during the previous three years, $41 \%$ participated in 3 or 4 activities, and $31.4 \%$ participated in 5 or more activities.

\subsection{Data Collection Instrument}

In the present study, "Views on Professional Work Conducted at the Beginning of the Academic Year" (VPWCBAY), "Views on Professional Work Conducted at the End of the Academic Year" (VPWCEAY), and "Views on the Satisfaction of Teachers' Requirements by Professional Work Topics" (VSTRPW) sections included in the teacher survey "Assessment of Professional Seminars for Preschool Teachers," section "Views on Professional Work" developed by Ministry of National Education Research and Development Directorate were used (MEB, 2006). The survey forms were 5-point Likert type scales scored between "completely" and "never", which are generally used in attitude measurements. The reliability coefficient of the survey was 0.96 . In the present study, it was determined that the Cronbach Alpha reliability coefficient was 0.88 


\subsection{Data Analysis}

The data obtained in the study were analyzed with the SPSS for Windows 21.0 software. The skewness and kurtosis were examined to determine the normal distribution of the dataset and it was found that the skewness and kurtosis values for location, seniority and participation in activities variables were between -2.0 and +2.0 and the same values were above +2.0 for the gender variable (George and Mallery, 2014). Therefore, in the present study, parametric tests were applied for the variables with normal distribution and non-parametric tests were applied for the variables without normal distribution. The Mann Whitney U-Test and Independent Samples t-Test were used to compare the quantitative data for two groups, and one-way ANOVA was used in the comparison of parameters between the groups where more than two groups were present. Descriptive statistical methods (counts, percentages, mean, standard deviation, etc.) were used for data analysis.

\section{Results}

This section includes the findings obtained in the analysis of the study data.

Table 2. The Views of Preschool Teachers on Professional Work

\begin{tabular}{|c|c|c|c|c|c|}
\hline & Total & Min. & Max. & $\bar{X}$ & Sd \\
\hline VPWCBAY & 105 & 2.48 & 4.78 & 3.49 & .45 \\
\hline VPWCEAY & 105 & 1.86 & 5.00 & 3.35 & .59 \\
\hline VSTRPW & 105 & 1.50 & 5.00 & 3.10 & .67 \\
\hline
\end{tabular}

The Table 2. demonstrates that the views of preschool teachers on professional work were at good levels for VPWCBAY, VPWCEAY, and VSTRPW.

Table 3. The Analysis of the Views of Preschool Teachers on Professional Work Based on Gender

\begin{tabular}{cccccccc}
\hline & Gender & N & Mean Rank & Rank Total & U & p & Difference \\
\hline \multirow{2}{*}{ VPWCBAY } & Female & 94 & 53.18 & 4999.00 & 500.0 & .859 & - \\
& Male & 11 & 51.45 & 566.00 & & & - \\
\multirow{2}{*}{ VPWCEAY } & Female & 94 & 53.92 & 506.50 & 430.5 & .364 & \\
& Male & 11 & 45.14 & 496.50 & & & - \\
VSTRPW & Female & 94 & 52.71 & 4955.00 & 490.0 & .777 & - \\
& Male & 11 & 55.45 & 610.00 & & \\
\hline
\end{tabular}

$\mathrm{p}<0.05$

Based on the Table 3. Mann Whitney U-Test, conducted to determine whether there was a difference between the views of preschool teachers on professional work based on the gender variable, demonstrated that there was no statistically significant difference between VPWCBAY $(\mathrm{U}=500,0 ; \mathrm{p}=.859>.05)$, VPWCEAY $(\mathrm{U}=430.5 ; \mathrm{p}$ $=.364>.05)$ and VSTRPW $(\mathrm{U}=490.0 ; \mathrm{p}=.777>.05)$.

Table 4. The Analysis of the Views of Preschool Teachers on Professional Work Based on Location

\begin{tabular}{ccccccccc}
\hline & Location & $\mathbf{N}$ & $X$ & Ss & Sd & t & p & Difference \\
\hline \multirow{2}{*}{ VPWCBAY } & İl & 74 & 3.52 & .44 & \multirow{2}{*}{103} & 1.284 & .202 & - \\
\multirow{2}{*}{ VPWCEAY } & İlçe & 31 & 3.40 & .46 & & & .229 & - \\
\multirow{2}{*}{ VSTRPW } & İl & 74 & 3.39 & .57 & \multirow{2}{*}{103} & 1.209 & .768 & - \\
\hline
\end{tabular}

$\mathrm{p}<0.05$ 
Based on the Table 4. independent samples t-test, conducted to determine whether there was a difference between the views of preschool teachers on professional work based on the location variable, demonstrated that there was no statistically significant difference between VPWCBAY $(\mathrm{t}=1.284 ; \mathrm{p}=.202>.05)$, VPWCEAY $(\mathrm{t}=1.209 ; \mathrm{p}=.229>.05)$ and VSTRPW $(\mathrm{t}=-.296 ; \mathrm{p}=.768>.05)$.

Table 5. The Analysis of the Views of Preschool Teachers on Professional Work Based on Seniority

\begin{tabular}{lccccccc}
\hline & $\begin{array}{c}\text { Source of the } \\
\text { Variance }\end{array}$ & $\begin{array}{c}\text { Sum of } \\
\text { Squares }\end{array}$ & $\begin{array}{c}\text { Degree of } \\
\text { Freedom }\end{array}$ & $\begin{array}{c}\text { Mean of } \\
\text { Squares }\end{array}$ & F & P & Difference \\
\hline \multirow{2}{*}{ VPWCBAY } & Between Groups & .757 & 4 & .189 & & & \\
& In-Group & 20.672 & 100 & .207 & .915 & .458 & - \\
& Total & 21.429 & 104 & & & & \\
VPWCEAY & Between Groups & 2.042 & 4 & .510 & & & \\
& In-Group & 34.260 & 100 & .343 & 1.490 & .211 & - \\
& Total & 36.302 & 104 & & & & \\
VSTRPW & Between Groups & .711 & 4 & .178 & & & \\
& In-Group & 46.613 & 100 & .466 & .381 & .822 & \\
\hline
\end{tabular}

$\mathrm{p}<0.05$

Based on the Table 5. ANOVA, conducted to determine whether there was a difference between the views of preschool teachers on professional work based on seniority variable, demonstrated that there was no statistically significant difference between VPWCBAY $(\mathrm{F}=.915 ; \mathrm{p}=.458>.05)$, VPWCEAY $(\mathrm{F}=1.490 ; \mathrm{p}=.211>.05)$ and VSTRPW $(\mathrm{F}=.381 ; \mathrm{p}=.822>.05)$.

Table 6. The Analysis of the Views of Preschool Teachers on Professional Work Based on Participation in the Activities

\begin{tabular}{cccccccc}
\hline & $\begin{array}{c}\text { Source of the } \\
\text { Variance }\end{array}$ & $\begin{array}{c}\text { Sum of } \\
\text { Squares }\end{array}$ & $\begin{array}{c}\text { Degree of } \\
\text { Freedom }\end{array}$ & $\begin{array}{c}\text { Mean of } \\
\text { Squares }\end{array}$ & F & P & Difference \\
\hline \multirow{3}{*}{ VPWCBAY } & Between Groups & .913 & 2 & .457 & & & \\
& In-Group & 20.516 & 102 & .201 & 2.270 & .109 & - \\
& Total & 21.429 & 104 & & & & \\
VPWCEAY & Between Groups & 1.340 & 2 & .670 & & & \\
& In-Group & 34.962 & 102 & .343 & 1.955 & .147 & - \\
& Total & 36.302 & 104 & & & & \\
VSTRPW & Between Groups & .284 & 2 & .142 & & & - \\
& In-Group & 47.040 & 102 & .461 & .308 & .736 & - \\
\hline
\end{tabular}

$\mathrm{p}<0.05$

Based on the Table 6. ANOVA, conducted to determine whether there was a difference between the views of preschool teachers on professional work based on their participation in vocational activities during the previous three years, demonstrated that there was no statistically significant difference between VPWCBAY $(\mathrm{F}=2.270 ; \mathrm{p}=.109>.05)$, VPWCEAY $(\mathrm{F}=1.955 ; \mathrm{p}=.147>.05)$ and VSTRPW $(\mathrm{F}=.308 ; \mathrm{p}=.736>.05)$.

\section{Conclusion}

Professional work conducted at the beginning, during and at the end of the academic year by preschool teachers within the context of in-service training is important for both the teachers and preschool education regarding the quality of the educational services they would provide during their professional lives, currency of their knowledge and a productive educational and instructional process.

Mann Whitney U-Test, conducted to determine whether there was a difference between the views of preschool teachers on professional work based on the gender variable, demonstrated that there was no statistically significant difference between VPWCBAY. 
Independent samples t-test, conducted to determine whether there was a difference between the views of preschool teachers on professional work based on the location variable, demonstrated that there was no statistically significant difference between VPWCBAY

The study findings demonstrated that the views of pre-school teachers on professional work were at good levels for VPWCEAY and VSTRPW. However, there were no significant differences between the pre-academic year and post-academic year views of pre-school teachers on the professional work and the ability of professional work topics to satisfy their needs based on gender, seniority in the profession, location of employment and participation in vocational activities during the previous three years.

\section{Discussion}

It was reported that certain knowledge that teachers acquire during the course of their pre-service or in-service training could lose its validity in a short period of time and thus, it is necessary to constantly supplement the teachers' knowledge with professional studies (Şişman, 1999). Zembat and Bilgin (1966) concluded that in-service training programs provided for teachers did not fulfill their intended objectives in a study they conducted. On the other hand, activities such as vocational courses, seminars, conferences and symposiums, which teachers attend, contribute to teachers in developing annual, unit and daily plans and personal strategies to organize the classroom environment, and better utilize the information and communication technologies (computers, overhead projectors, videos, slides, etc.) (MEB, 2006). In the present study, it was demonstrated that teachers' participation in activities on professional work in the previous three years did not change their views on professional work. It can be suggested to question the effectiveness and efficiency of the conducted professional work.

Vocational studies should be updated every year in line with the needs and wishes of teachers. Special education should be provided for the teachers on the inclusive education students. Further rigorous studies should be conducted on practical stages of the activities in order to improve the efficiency of professional work activities and to maximize the benefits of the studies for the teachers. Preliminary information should be provided for teachers on the activities on professional studies to increase teacher participation. Teachers should be encouraged to participate more actively in all aspects of the process.

\section{References}

Acun, S., \& Erten, G.B. (1993). Kız meslek liseleri için okul öncesi eğitimi. İstanbul: Esin Yayınevi.

Celep, C. (Ed.). (2010). Eğitim bilimine giriş .Ankara: Anı Yayıncılık.

Demirel, Ö., \& Kaya, Z. (Ed.). (2014). Eğitim bilimine giriş. Ankara: Pegem Akademi.

Demirel, Ö., Seferoğlu, S., \& Yağc1, E. (2001). Öğretim teknolojileri ve materyal geliştirme. Ankara: Pegem Akademi Yayıncilık.

Ergün, M. (1996). Ĕgitim felsefesi. Ankara: Ocak Yayınları.

George, D., \& Mallery, P. (2014). IBM SPSS Statistics 21 Step by Step: A Simple Guide and Reference (13th Ed.). New Jersey: Pearson Education, Inc.

Gürdal, A., Sağırlı, M., \& Üredi, L. (2000). Okul deneyimi-1'in öğretmen adayı ve uygulama öğretmeni üzerindeki etkileri. VIII. Ulusal Eğitim Bilimleri Kongresi Bilimsel Çalışmaları, 1, 59-568.

Karasar, N. (2013). Bilimsel araş̧tırma yöntemi (25. bs.). Ankara: Nobel Yayın Dağııım.

Kavcar, C. (1988). Geleceğin teknolojileri. Öğretmen Yetişstiren Yüksek Öğretim Kurumlarının Dünü- BugünüGeleceği Seтроzуити (8-11 Haziran 1987) içinde. Ankara: Gazi Ü. Yayınları.

Konakl1, N. (1992). Kalkinma planlarında ve ylllık programlarda okulöncesi eğitim: YA-PA 8. Okul öncesi eğitimi ve yaygınlaştırılması semineri. İstanbul: YA-PA Yayınları.

Millî Eğitim Bakanlığı (2017). Öğretmenlerin 2017 Eylül dönemi mesleki gelişim çalışmaları. Retrieved from https://oygm.meb.gov.tr/meb_iys_dosyalar/2017_08/28191925_EK_Mesleki_YalYYmalar_ProgramY_EylY1_2 017.pdf adresinden 01.01.2018 tarihinde edinilmiş̧ir

Millî Eğitim Bakanlığı Eğitimi Araştırma ve Geliştirme Dairesi Başkanlığı. (2006). İlköğretim okulu öğretmenlerinin yaptıkları mesleki seminer çalışmalarının değerlendirilmesi. Ankara: Milli Eğitim Bakanlığı Yayınları. Retrieved adresinden 02.04.2017 from https://www.meb.gov.tr/earged/earged/senebasi_seminer_calismalari.pdf 
tarihinde edinilmiştir.

Oktay, A. (1993). Okul öncesi eğitim kurumlarının sorunlarl ve öneriler: YA-PA okul öncesi eğitimi ve yaygınlaştırılması semineri (2. bs.). İstanbul: YA-PA Yayınları.

Şişman, M. (1999). Öğretmenlik mesleğine giriş. Ankara: Pegem Akademi Yayıncılık.

Tandoğan, M. (2001). Türkiye'de Eğitim -İnsan Yetiştirme- Biliminin Analizi. Eğitim Araştırmaları, 5, 93-95.

Türk Dil Kurumu (2018). Genel Türkçe sözlük. Retieved adresinden 19.01.2018 tarihinde edinilmiştir from http://www.tdk.gov.tr

Türkoğlu, A. (1994). 99 Soruda Eğitim Bilimine Giriş. (2. bs.). İzmir: Memleket Gazetecilik ve Matbaacılık.

Ulcay, S. (1983). Okulöncesi çocuk gelişimi ve eğitimi kurumlarında yıllık plan. İstanbul: Milli Eğitim Basımevi.

Varış, F. (1973). Cumhuriyetin 50. yılında Türkiye'de öğretmen yetiştirmede karşılaşılan birkaç sorun. Cumhuriyetin 50. Yılına Armağan. Ankara: Ankara Üniversitesi Yayınları.

Yılmaz, N. (1991). Anaokulu öğretmeninin rehber kitabı. (1. bs.). İstanbul: YA-PA Yayınları.

Zembat, R., \& Bilgin, H. (1996). Okul öncesi eğitim kurumlarında çalışan ögretmenlerin öğretmenlik tutumlarının incelenmesi. II. Ulusal Eğitim Sempozyumu Bildirileri içinde (18-20 Eylül 1996). İstanbul. 